\title{
COMPARATIVE ANALYSIS OF PUBLIC HEALTH RISK DETERMINED BY CHEMICAL CONTAMINATION OF DIFFERENT TYPES OF FOOD PRODUCTS
}

\author{
V.V. Fetter, A.D. Polyakov
}

Department of the Federal Service on Customers' Rights Protection and Human Well-Being Surveillance in Belgorod region, Russian Federation, Belgorod, Zeleznyakova St., 2, 308023 Federal Autonomous Educational Establishment for Higher Professional Education "Belgorod State National Research University", Russian Federation, Belgorod, Pobedy St., 85, 308015

\begin{abstract}
The article presents the results of risk comparative analysis and assessment of public health determined by usage of various types of chemically contaminated food products. The significance of local and imported food products to Belgorod region in formation of public exposure to top-priority chemical contaminants has been identified. The article includes integrated comparative assessment of chemical contaminants' contribution as well as of the several groups of products that form the markers of individual and public carcinogenic or noncarcinogenic risk upon the consumption of various types of food products. The article shows comparative analysis levels of carcinogenic or non-carcinogenic risk determined by the consumption of imported products.

Key words: origin of food products, chemical contaminants of food products, pro rate contribution in public health risk, risk comparative assessment, attributive risk.
\end{abstract}

Politics, strategy and prioritizing actions aimed at the most efficient, economically justified reduction of negative influence on population health are based in the majority of world countries and organizations on the conception of risk assessment. The notion of population health risk assessment under the influence of chemical, physical and biological factors became an integral part of the legislation in the sphere of providing products safety and protecting state population health in the states - Customs Union members and the whole world community $[5,6]$.

According to WHO (World's Health Organization) estimations, trade globalization at the current stage has led not only to higher availability and variety of food products in the world but also increased the probability that the goods produced in one place might influence the health and diet of people living in another place [14].

According to A. M. Vasilovskiy [1], hygienic problems of providing population with food products, their safety for health and influence on morbidity of the population were detected in Slovakia (D. Pavlovicova et al., 2008), Poland (A. Nowacka et al., 2009), New Zealand (P. Gressey et al., 2009), China (L. Calvin et al., 2006), the USA (J. Ender et al., 2008), Sweden (M. Cantley, 2008), France (A. Tard et al., 2007), South Africa (G.S. Shephard, 2008), Canada (S.A. Tittlemier et al., 2007), the Netherlands (W.R. Leeman et al., 2007),

${ }^{\odot}$ Fetter V.V., Polyakov A.D., 2014

Fetter Vladimir Vilmarovich - Candidate of Medical Science, Deputy Head, Associate professor (e-mail: Fetter_VV@31.rospotrebnadzor.ru; tel.: phone+7 (4722) 34-30-27).

Polyakov Andrei Dmitrievich - Candidate of Medical Science, Head, Senior lecturer (e-mail: postoscol@mail.ru; tel.: $+7(4722)$ 34-03-16). 
Nigeria (M.N. Anokwulu, 2007), Spain (D. Gonzalez-Weller et al., 2006), Great Britain (R.J. McCracken et al., 2007), Italy (G.C. Cortellezzi et al., 2005).

Numerous researches conducted over the recent years have shown that the top contaminants forming high risk of malignant tumours and development of non-carcinogenic effects among the population in the Regions of the Russian Federation are cadmium, arsenic and lead contaminating dairy, meat, fish and pastry products as well as nitrates, hexachlorane (HXCHL) and dichloro-diphenyl-trichloroethane (DDT) contained in vegetable products [1-3, 4, 7-13, 17, 19-22].

The above-given confirms the significance of evidence on the origin of chemically contaminated food stock (FS) and food products (FP) when justifying the decisions on risk management conditioned by consumption of the given food products.

The starting point for conducting a serious and deep research was materials of works ${ }^{1}$ on detecting priority chemical contaminants of FS and FP, determining the groups of food products presenting risk for population health and conditioned by consumption of FP contaminated by cadmium $(\mathrm{Cd})$, arsenic $(\mathrm{As})$, hydrargyrum $(\mathrm{Hg})$, lead $(\mathrm{Pb})$, nitrates, HXCHL and DDT.

The aim of the work is to assess the role of FS and FP of various origins in population health risk formation which is conditioned by consumption of chemically contaminated food products. The tasks for achieving the set goal: definition of the exposition and the assessment of the risk of chemical contaminants influence in FP with account of their origin; determination of critical territories of FP origin according to the level of chemical contamination; working out suggestions on improving the exposition control and risk of FS and FP chemical contaminants influence on population.

Materials and methods. The research was based on studying and analyzing the data of laboratory research of FS and FP over $2011^{2}$ included into Belgorod Regional Information Fund of Social and Hygienic Monitoring (RIF SHM) ${ }^{3}$.

\footnotetext{
${ }^{1}$ Fetter V. V., Berdinskikh N. N., Zavyalova N.A. Assessment of the condition of chemical contamination of food products // Sanitary Doctor. - 2011. - № 9. - pp. 20-23; Fetter V.V. Assessment of population health risk from chemical contamination of food products and food stock // Health risk analysis. - 2013. - № 4. - pp. 54-63.

${ }^{2}$ Studies of food products were conducted by the laboratories of Federal Budget Healthcare Institution 'Center of hygiene and epidemiology in Belgorod region' accredited in the established order

${ }^{3}$ RIF SHM - Regional Information Fund of Social-Hygienic Monitoring.
} 
The studied FS and FP were produced in Belgorod region (BR), in 18 subjects of the Russian Federation $\left(\mathrm{SRF}^{1}\right)$, in 2 countries of the Commonwealth of Independent States (CIS ${ }^{2}$ ) and in 13 far-abroad countries $\left(\mathrm{FAC}^{3}\right)$.

To assess the results there were selected 5,865 samples of FS and FP studied on the subject of containing cadmium, arsenic, quicksilver, lead, nitrates, HXCHL and DDT considered as top contaminants of food products in BR according to the materials of the previously held studies [20, 21].

Original data processing ${ }^{4}$, determination of contaminants presence, calculation of exposition, interpretation of the obtained results was conducted in accordance with the recommendations of the Federal Service of Supervision of Consumer Rights Protection and Human Welfare ${ }^{5}$.

To calculate the exposition and assess the risks of non-carcinogenic and carcinogenic effects conditioned by chemical contamination of food products there were used average values and $90^{\text {th }}$ percentile of the upper border of centile trend distribution.

The indicators of health risk of the population were calculated for two subpopulations children (0-6 years) and adults (18 and older) with the account of the data on per capita consumption of food products ${ }^{6}$.

The criteria of assessing health risks from cadmium, arsenic, quicksilver, lead, nitrates, HXCHL and DDT are officially recommended data on reference (safe) concentrations at chronic impacts, impacted critical organs and body systems, daily average maximum concentrations determined on the basis of direct toxic effects on health and so on $[15,16,18]$.

Results and their discussion. The occurrence of studied FS and FP contamination in BR in 2011 under the program of SHM and included into this study on average made: on the

\footnotetext{
${ }^{1}$ Bryansk region; Volgograd region; Voronezh region; Kaliningrad region; Krasnodar region; Kurgan region; Kursk region; Moscow city; Moscow region; Murmansk region; Orlov region; Primorskiy region; Rostov region; SaintPetersburg; Saratov region; Stavropol region; Tula region; Chelyabinsk region, from the territories of which food products were delivered to BR in 2011.

${ }^{2}$ Belorussia, Kazakhstan, Ukraine from the territories of which food products were delivered to BR in 2011.

${ }^{3}$ Argentina; Virgin Islands; Vietnam; Egypt; Israel; India; Ireland; Spain; China; the Netherlands; the USA; Turkey; France; from the territories of which food products were delivered to BR in 2011.

${ }^{4}$ The work with the database 'Contamination of food stock and food products by chemical substances' RIF SHM, including statistic processing of the materials was effected by the specialists of SHM department of Federal Service for Consumer Rights Protection and Human Welfare in Belgorod region under the guidance of the author.

${ }^{5} \mathrm{P}$ 2.1.10.1920-04 «Guidance on assessment of population health risk under the influence of chemical substances polluting the environment»; MU 2.3.7.2519-09 «Determination of exposition and assessment of risk from influence of chemical contaminants in food products on population»

${ }^{6}$ The average per capita food consumption data were used for the studies. The data were provided by the Territorial Institution of the Federal Statistics Services in Belgorod region (Belgorodstat).
} 
presence of nitrates $-99.2 \%$; lead $-84.2 \%$; cadmium $-83.3 \%$; arsenic $-24.5 \%$; quicksilver $13.9 \%$ from the number of probed samples studied for each contaminant ${ }^{1}$.

As for the data of the conducted studies (table 1) potatoes belong to the groups of FP with the greatest contribution to exposition of the population with lead (33.43\%) alongside with bread products $(32.67 \%)$ and fish products $(19.45 \%)$. The main contribution to the exposition of cadmium while consuming local products by the population of BR is made by potatoes $(45.24 \%)$ and food products $(32.71 \%)$ and when speaking about imported products delivered from subjects of the RF (SRF) these are again - potatoes (39.65\%) and fish products $(37.60 \%)$.

Table 1

\section{Comparative data of contribution into exposition by lead and cadmium of local (BR) and imported (SRF) food products in 2011}

\begin{tabular}{|l|c|c|c|c|c|c|}
\hline \multirow{2}{*}{ Name of food products groups } & \multicolumn{3}{|c|}{$\begin{array}{c}\text { Contribution of products into lead } \\
\text { exposition, \% }\end{array}$} & \multicolumn{3}{c|}{$\begin{array}{c}\text { Contribution of products into cadmium } \\
\text { exposition, \% }\end{array}$} \\
\cline { 2 - 8 } & BR & SRF & Average value & BR & SRF & Average value \\
\hline Bread products & 33.49 & 31.86 & 32.67 & 32.71 & 8.54 & 20.62 \\
\hline Potatoes & 38.96 & 27.89 & 33.43 & 45.24 & 39.65 & 42.44 \\
\hline Fish products & 17.27 & 21.64 & 19.45 & 4.67 & 37.60 & 21.14 \\
\hline
\end{tabular}

The greatest role in forming lead exposition for the population conditioned by FP consumption is played by fish products and nuts, the amount of contribution of which when consuming local products (BR) was 73.42 and 21.98\% accordingly; and when consuming products imported from SRF - 24.25 and $64.49 \%$ accordingly.

Lead exposition of the population was estimated entirely because of consuming FP produced in $\mathrm{BR}^{2}$. At that, the greatest contribution was made by vegetables $(36.55 \%)$, meat products $(26.37 \%)$ and bread products $(22.93 \%)$.

To the group with the greatest contribution to nitrate contamination of FP produced in BR we referred beetroot $-30.15 \%$, early cabbage $-21.72 \%$ and potatoes $-16.78 \%$. When talking about consumption of the imported products (table 2), the greatest exposition by nitrates is made by potatoes and cabbage (SRF - 33.60 and $33.02 \%$; CIS - 75.52 and 19.56\%; far-abroad countries -50.20 and $13.95 \%$ accordingly). At that, the contribution into nitrate exposition of potatoes imported from SRF, FAC and CIS was 2.00 times; 2.99 times and 4.50 times higher than from potatoes grown in the territory of BR.

\footnotetext{
${ }^{1}$ The number of probe samples studied for nitrates - 1,116; lead - 1,271; cadmium - 1,268; arsenic - 1,091; quicksilver - 1,119. HXCHL and DDT were not detected in the studied samples of FS and FP.

${ }^{2}$ Bread products; oil and other fats; milk and dairy products; meat and meat products; vegetables; sugar and confectionary.
} 
Table 2

Comparative data of nitrate exposition contribution by local (BR) and imported food products (SRF, CIS, FAC) in 2011

\begin{tabular}{|l|c|c|c|c|}
\hline \multirow{2}{*}{ Group products names } & \multicolumn{4}{|c|}{ Nitrate exposition contribution by food products, \% } \\
\cline { 2 - 5 } & BR & SRF & CIS & FAC \\
\hline Early cabbage & 21.72 & 33.02 & 19.56 & 13.95 \\
\hline Potatoes & 16.78 & 33.60 & 75.52 & 50.20 \\
\hline
\end{tabular}

The description of risk of evolvement of non-carcinogenic effects for separate contaminants coming with FP in the conditions of prolonged influence was conducted on the basis of calculating danger index $(H Q)^{1}$.

The size of $H Q_{C d}, H Q_{P b}$ and $H Q_{H g}$ of the studied groups of FP in all the sources of origin (BR, SRF, FAC) and $H Q_{\text {нитр }}$ of FP produced in BR with calculated level of adult population exposition is within the range of 0.003 to 0.75 (doesn't exceed 1.0) which confirms the permissible level of non-carcinogenic risk.

The level of non-carcinogenic risk calculated in respect of children population exposition also did not exceed 1.0 and made: $H Q_{C d}$ of FP delivered from SRF - from 0.31 to $0.83 ; H Q_{P b}$ of FP delivered from far-abroad countries - from 0.09 to $0.56 ; H Q_{H g}$ of FP delivered from SRF and far abroad countries - from 0.06 to 0.85 .

Exceeding the level of permissible non-carcinogenic risk for children population is established on separate groups of products produced: in BR $\left(H Q_{C d}-\right.$ from 0.03 to $1.49 ; H Q_{P b}-$ from 0.001 to $1.48 ; H Q_{H g}$ - from 0.04 to $1.16 ; H Q_{\text {нитр }}$ - from 0.20 to 8.80); in SRF ( $H Q_{P b}$ - from 0.06 to $1.83 ; H Q_{H u m p}$ - from 0.32 to 3.52$)$; in far-abroad countries $\left(H Q_{C d}\right.$ - from 0.14 to 1.03 ; $H Q_{\text {нитр }}$ - from 0.20 до 2.02).

Maximum levels of non-carcinogenic effects probability connected with consumption of chemically contaminated FP are established for children (0-6 years):

- on FP produced in $\mathrm{BR}$ - bread products $\left(H Q_{C d}=1.49 ; H Q_{P b}=1.48\right)$, fish products $\left(H Q_{H g}=1.16\right)$, potatoes $\left(H Q_{\text {нитр }}=1.77\right)$, vegetables $\left(H Q_{\text {нитр }}=8.80\right)$;

- on FP produced in SRF - bread products $\left(H Q_{P b}=1.83\right)^{2}$, potatoes $\left(H Q_{\text {нump }}=1.69\right)^{3}$, vegetables $\left(H Q_{\text {нитр }}=3.52\right)^{4}$;

- $\quad$ on FP produced in far-abroad countries - fish products $\left(H Q_{C d}=1.03\right)^{5}$, potatoes $\left(H Q_{\text {нитр }}=2.02\right)^{6}$, vegetables $\left(H Q_{\text {нитр }}=1.71\right)^{7}$.

\footnotetext{
${ }^{1}$ Calculation of $H Q$ was done on separate FP and groups of studied FP on: cadmium $\left(H Q_{C d}\right)$, quicksilver $\left(H Q_{H g}\right)$, lead $\left(H Q_{P b}\right)$ and nitrates $\left(H Q_{\text {нuтр }}\right)$ with the account of the FS and FP territories of production.

${ }^{2}$ Origin of bread products: Volgograd region, Voronezh region, Krasnodar region, Kurgan region, Moscow, Orel region, Rostov region, Saint-Petersburg, Saratov region, Stavropol region, Chelyabinsk region.

${ }^{3}$ Origin of potatoes: Bryansk region.

${ }^{4}$ Origin of vegetables: Rostov region.

${ }^{5}$ Origin of fish products: Vietnam.

${ }^{6}$ Origin of potatoes: Israel, India, the Netherlands, Turkey.

${ }^{7}$ Origin of vegetables: Virgin Islands, Egypt, Israel, India, Spain, the Netherlands, Turkey.
} 
Non-carcinogenic risk conditioned by the presence of arsenic in FP produced in BR calculated for the adult population exposition did not exceed 1.0, with this, the amount of $H Q_{A s}$ was in the range of 0.001 to 0.42 . Exceeding the permissible level of $H Q_{A s}$ is also determined for children's population on the contents of arsenic in vegetables $\left(H Q_{A s}=1.30\right)$ calculated by the average centile trend as well as the amount of arsenic in sugar and confectionary $\left(H Q_{A s}=1.0\right)$, bread products $\left(H Q_{A s}=1.43\right)$, meat products $\left(H Q_{A s}=1.45\right)$ and vegetables $\left(H Q_{A s}=1.95\right)$.

The risk of development of non-carcinogenic effects under the conditions of simultaneous and prolonged impact of cadmium, quicksilver, lead and nitrates getting into the organism as a result of consumption of all FP was estimated on the basis of danger index $(H I)$ for each contaminant $^{1}$ and total amount of danger index $(\Sigma H I)^{2}$.

The greatest contribution to the total danger index $(\Sigma H I)$ conditioned by contamination of all the researched in 2011 food products (table 3) is made by nitrates - 32.74\% and lead $30.98 \%$, the contribution of quicksilver, cadmium and arsenic was from $10.17 \%$ to $14.82 \%$.

The consumption of FP produced in SRF and FAC increases the risk of non-carcinogenic

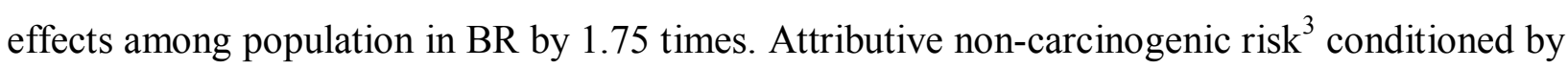
the amount priority contaminants in FP produced in SRF and FAC made from $46.12 \%$ to $61.03 \%$.

Table 3

Comparative data on the level of non-carcinogenic risk $(H I)$ conditioned by top chemical contaminants of food products in 2011

\begin{tabular}{|c|c|c|c|c|c|}
\hline \multirow{2}{*}{$\begin{array}{l}\text { FS and FP } \\
\text { contaminants }\end{array}$} & \multicolumn{3}{|c|}{ Danger index $(H I)$} & \multirow{2}{*}{$\begin{array}{c}\text { Contaminants' } \\
\text { contribution into } \\
\sum H I(\%)\end{array}$} & \multirow[b]{2}{*}{$A R(\%)$} \\
\hline & $H I_{\mathrm{BR}}$ & $H I_{\sum(\mathrm{SRF}: \mathrm{FAC})}$ & $\Sigma H I$ & & \\
\hline Cadmium & 3.25 & 5.09 & 8.34 & 11.29 & 61.03 \\
\hline Quicksilver & 3.66 & 3.85 & 7.51 & 10.17 & 51.26 \\
\hline Lead & 11.29 & 11.60 & 22.89 & 30.98 & 50.67 \\
\hline Arsenic & 10.95 & - & 10.95 & 14.82 & - \\
\hline Nitrates & 13.03 & 11.16 & 24.19 & 32.74 & 46.12 \\
\hline Total & 42.18 & 31.69 & 73.87 & 100.00 & \\
\hline
\end{tabular}

Note: $H_{\mathrm{BR}}$ - danger index (non-carcinogenic risk) conditioned by consumption of FP produced in BR; $H I_{\Sigma \text { (SRFFAC) }}$ - danger index (non-carcinogenic risk) conditioned by the consumption of FP produced in SRF and FAC; $\Sigma H I$ - total danger index (non-carcinogenic risk) conditioned by FP consumption produced in BR, SRF and FAC; $A R$ - attributive non-carcinogenic risk conditioned by consumption of FP produced in SRF and FAC.

\footnotetext{
${ }^{1}$ Danger indexes $H I$ for cadmium, quicksilver, lead and nitrates calculated by $H Q$ for all FP groups depending on their origin (BR, SRF and FAC).

${ }^{2}$ Total amount $H I(\Sigma H I)$ on each top contaminant $(\mathrm{Cd}, \mathrm{Hg}, \mathrm{Pb}$, nitrates) of all the groups of $\mathrm{FP}$ with the account of their origin (BR, SRF, FAC).

${ }^{3}$ Attributive (additional) risk (AR) - risk share conditioned by the impact of the studied factor - probability of health problems (in $\%$ from the amount of health problems in the studied population) connected with the studied factor.
} 
The study of the role of separate groups of chemically contaminated FP in forming noncarcinogenic risk (table 4) shows the greatest contribution made by vegetables $-40.55 \%$, with this the total amount of bread products, fish products and potatoes made $50.72 \%$ and oil and fat, fruit and berries products, sugar and confectionary $-8.76 \%$.

From the total number of the studied FP in BR and produced in SRF and FAC, the greatest contribution to forming non-carcinogenic effects among the population is made by: fruit and berries, potatoes, fish and oil and fat products. The amount of attributive non-carcinogenic risk $70.94 \% ; 62.78 \% ; 58.6 \%$ and $53.12 \%$ accordingly.

In accordance with written sources $[16,18]$ used while compiling table 5 , the following systems are most intensely impacted by the number of studied FP contaminants: endocrine system (cadmium, quicksilver, lead, arsenic); central nervous system and blood circulation systems (quicksilver, lead, arsenic).

Table 4

Comparative data on the level of non-carcinogenic risk $(H I)$ conditioned by chemical contamination of various groups of food products 2011

\begin{tabular}{|c|c|c|c|c|c|}
\hline \multirow{2}{*}{ FP group } & \multicolumn{3}{|c|}{ Danger index $(H I)$} & \multirow{2}{*}{$\begin{array}{l}\text { FP contribution } \\
\text { into } \sum \text { HI }(\%)\end{array}$} & \multirow{2}{*}{$A R(\%)$} \\
\hline & $H I_{\mathrm{BR}}$ & $H I_{\sum(\mathrm{SRF}: \mathrm{FAC})}$ & $\sum H I$ & & \\
\hline Bread products & 2.58 & 1.62 & 4.2 & 17.24 & 38.45 \\
\hline Oil and fats & 0.22 & 0.25 & 0.48 & 1.97 & 53.12 \\
\hline Fruits and berries & 0.18 & 0.43 & 0.61 & 2.49 & 70.94 \\
\hline Potatoes & 1.74 & 2.94 & 4.68 & 19.22 & 62.78 \\
\hline Vegetables & 6.62 & 3.25 & 9.88 & 40.55 & 32.90 \\
\hline Fish products & 1.43 & 2.04 & 3.47 & 14.25 & 58.61 \\
\hline Sugar, confectionary & 0.66 & 0.39 & 1.05 & 4.31 & 37.19 \\
\hline Total & 13.44 & 10.92 & 24.36 & 100.01 & \\
\hline
\end{tabular}

Note: $H I_{\mathrm{BR}}$ - danger index (non-carcinogenic risk) conditioned by the consumption of FP produced in BR; $H I_{\Sigma \text { (SRFFAC) }}$ - danger index (non-carcinogenic risk) conditioned by the consumption of FP produced in SRF and FAC; $\Sigma H I$ - total danger index (non-carcinogenic risk) conditioned by consumption of FP produced in BR, SRF and FAC; $A R$ - attributive non-carcinogenic risk conditioned by consumption of FP produced in SRF and FAC.

Table 5

The assessment of critical organs and body systems damage under development of noncarcinogenic effects conditioned by chemical contamination of food products in 2011

\begin{tabular}{|c|c|c|c|c|c|c|c|}
\hline \multirow[b]{2}{*}{$\begin{array}{c}\text { Affected organs } \\
\text { and systems }\end{array}$} & \multirow[b]{2}{*}{$\begin{array}{l}\text { Contaminants } \\
\text { affecting organs } \\
\text { and systems }\end{array}$} & \multicolumn{4}{|c|}{ Danger index $(H I)$} & \multirow{2}{*}{\begin{tabular}{|} 
Contribution \\
of organs \\
and systems \\
into \\
$\sum H I(\%)$
\end{tabular}} & \multirow[b]{2}{*}{$A R(\%)$} \\
\hline & & $H I_{\mathrm{BR}}$ & $H I_{\mathrm{SRF}}$ & $H I_{\mathrm{FAC}}$ & $\sum H I$ & & \\
\hline Kidneys & $\mathrm{Cd}, \mathrm{Hg}$ & 2.36 & 2.03 & 1.28 & 5.67 & 7.67 & 58.33 \\
\hline Hormones & $\mathrm{Cd}, \mathrm{Hg}, \mathrm{Pb}, \mathrm{As}$ & 6.43 & 3.48 & 1.75 & 11.66 & 15.78 & 44.86 \\
\hline CNS & $\mathrm{Hg}, \mathrm{Pb}, \mathrm{As}$ & 4.80 & 1.67 & 1.00 & 7.48 & 10.12 & 35.78 \\
\hline Nervous system & $\mathrm{Pb}, \mathrm{As}$ & 4.07 & 1.46 & 0.46 & 5.98 & 8.10 & 31.94 \\
\hline $\mathrm{CVS}$ & As, nitrates & 8.71 & 3.27 & 2.39 & 14.36 & 19.44 & 39.38 \\
\hline Blood & $\mathrm{Pb}$, nitrates & 8.40 & 4.72 & 2.84 & 15.96 & 21.61 & 47.36 \\
\hline Reproduction & $\mathrm{Hg}, \mathrm{Pb}$ & 2.61 & 1.67 & 1.00 & 5.29 & 7.16 & 50.57 \\
\hline Immune system & $\mathrm{Hg}, \mathrm{Pb}, \mathrm{As}$ & 4.80 & 1.67 & 1.00 & 7.48 & 10.13 & 35.76 \\
\hline Total & & 42.18 & 19.97 & 11.72 & 73.87 & 100.00 & \\
\hline
\end{tabular}

N ot e: horm. - endocrine system; CNS - central nervous system; nerv. syst. - peripheral nervous system; CVS cardiovascular system; blood - blood circulating system and indicators of peripheral blood; reproduction - 
reproductive system; immune system - immunity system. $H I_{\mathrm{SRF}}$ - danger index (non-carcinogenic risk) conditioned by consumption of products produced in SRF; $H I_{\mathrm{FAC}}$ - danger index (non-carcinogenic risk) conditioned by consumption of FP produced in FAC; $A R$ - attributive non-carcinogenic risk conditioned by consumption of FP produced in SRF and FAC.

The greatest contribution into forming non-carcinogenic risk $\left(\sum H I\right)$ is provided for the account of non-favourable effects on the side of blood circulating system and indicators of peripheral blood $(21.61 \%)$, cardio-vascular system (19.44\%) and endocrine system (15.78\%) of the body (table 5).

The consumption by the BR population of FP produced in SRF and FAC forms additional non-carcinogenic risk $(A R)$ the share of which makes $58.33 \%$ of all affected kidneys, $50.57 \%$ of reproduction system malfunctions, $47.36 \%$ of unfavourable effects of blood system work and $44.86 \%$ of endocrine system illnesses. Attributive non-carcinogenic risk for other critical organs and systems of the body (table 5) makes from $31.94 \%$ to $39.38 \%$.

The data analysis in table 6 indicates different roles of the studied contaminants in forming top non-carcinogenic damages to organs and body systems. Thus, the main contribution (68.34\%) into forming general toxic effects on the side of endocrine system is made by cadmium (35.90\%) and lead (32.44\%). Non-carcinogenic effects on the side of cardiovascular and blood circulating systems $-84.75 \%$ and $75.27 \%$ accordingly are formed under the influence of nitrates.

Table 6

The assessment of contribution of chemical contaminants and FP origin territories in the forming top non-carcinogenic damage to organs and body systems as for 2011

\begin{tabular}{|c|c|c|c|c|c|c|c|}
\hline \multirow{2}{*}{$\begin{array}{l}\text { Affected } \\
\text { organs and } \\
\text { systems }\end{array}$} & \multirow[b]{2}{*}{ FP contaminants } & \multicolumn{4}{|c|}{ Danger index $(H I)$} & \multirow{2}{*}{$\begin{array}{c}\text { Contribution of } \\
\text { FP } \\
\text { contaminants } \\
\text { into } \sum \text { HI }(\%)\end{array}$} & \multirow[b]{2}{*}{$A R(\%)$} \\
\hline & & $H I_{\mathrm{BR}}$ & $H I_{\mathrm{SRF}}$ & $H I_{\mathrm{FAC}}$ & $\sum H I$ & & \\
\hline \multirow{5}{*}{ Horm. } & $\mathrm{Cd}$ & 1.63 & 1.81 & 0.76 & 4.19 & 35.90 & 61.16 \\
\hline & $\mathrm{Hg}$ & 0.73 & 0.22 & 0.55 & 1.50 & 12.88 & 51.28 \\
\hline & $\mathrm{Pb}$ & 1.88 & 1.46 & 0.45 & 3.78 & 32.44 & 50.23 \\
\hline & As & 2.19 & - & - & 2.19 & 18.78 & - \\
\hline & Total & 6.43 & 3.48 & 1.75 & 11.66 & & \\
\hline \multirow{3}{*}{ CVS } & As & 2.19 & - & - & 2.19 & 15.25 & - \\
\hline & Nitrates & 6.52 & 3.27 & 2.39 & 12.17 & 84.75 & 46.47 \\
\hline & Total & 8.71 & 3.27 & 2.39 & 14.36 & & \\
\hline \multirow{3}{*}{ Blood } & $\mathrm{Pb}$ & 1.88 & 1.61 & 0.45 & 3.95 & 24.74 & 52.33 \\
\hline & Nitrates & 6.52 & 3.11 & 2.39 & 12.01 & 75.27 & 45.75 \\
\hline & Total & 8.40 & 4.72 & 2.84 & 15.96 & & \\
\hline
\end{tabular}

Note: horm. - endocrine system; CVS - cardiovascular system; blood - blood circulating system and indicators of peripheral blood; $\Sigma H I$ - total danger index (non-carcinogenic risk) conditioned by consumption of food products produced in $\mathrm{BR}, \mathrm{SRF}$ and $\mathrm{FAC} ; A R$ - attributive non-carcinogenic risk conditioned by consumption of FP produced in SRF and FAC.

The role of the differences of FP chemical contamination levels depending of their origin in forming top non-carcinogenic damage to organs and body systems is supported by the indicators of attributive risk (table 6). Consumption of FP produced in SRF and FAC increases 
the risk of non-carcinogenic damage of blood circulating and cardiovascular systems at the account of lead, quicksilver and cadmium impact by 50.23\%; $51.23 \%$ and $61.16 \%$ accordingly.

The assessment of appearance of non-carcinogenic effects among the population ${ }^{1}$ (tables $7,8)$ was conducted on the basis of the indicators' analysis of individual, population and attributive carcinogenic risk determined by consumption of FP contaminated by cadmium, lead and arsenic.

As for the data given in table 7, the amount of total $I C R_{C d}$ and $I C R_{P b}$ of adult and children population $(8.73 \mathrm{E}-05-1.14 \mathrm{E}-04)^{2}$ refers to the second range of risk $^{3}$ and is permissible. Total $I C R_{A s}$ of adult and children population ${ }^{4}$ (table. 8) is within the range $3.19 \mathrm{E}-03-1.28 \mathrm{E}-03$ refers to the third range of risk and is not permissible for the population on the whole.

Table 7

Indicators of carcinogenic risk to the population health conditioned by FP contamination with cadmium and lead in 2011

\begin{tabular}{|c|c|c|c|c|c|c|}
\hline \multirow{2}{*}{ FP contaminants } & \multirow{2}{*}{$\begin{array}{l}\text { Types of } \\
\text { risk }\end{array}$} & \multirow{2}{*}{$\begin{array}{c}\text { Studied } \\
\text { subpopulation } \\
\text { S }\end{array}$} & \multicolumn{3}{|c|}{ FP origin } & \multirow{2}{*}{ Total risk } \\
\hline & & & BR & SRF & FAC & \\
\hline \multirow{4}{*}{$\begin{array}{l}\text { Cadmium (Cd): } \\
C A S \text { 7440-43-9; } \\
S F_{\mathrm{o}}=0.38\left(\mathrm{mg} /(\mathrm{kg} \cdot \mathrm{day})^{-1}\right. \\
\text { IACS/EPA :1/B1 }\end{array}$} & \multirow{2}{*}{$I C R_{\mathrm{Cd}}$} & Adults & $7.77 \mathrm{E}-05$ & $1.21 \mathrm{E}-04$ & $4.88 \mathrm{E}-05$ & $2.48 \mathrm{E}-04$ \\
\hline & & Children & 4.63E-05 & $4.85 \mathrm{E}-05$ & $1.95 \mathrm{E}-05$ & $1.14 \mathrm{E}-04$ \\
\hline & \multirow{2}{*}{$P C R_{\mathrm{Cd}}$} & Adults & 98.78 & 153.95 & 62.09 & 314.96 \\
\hline & & Children & 5.01 & 5.25 & 2.12 & 12.38 \\
\hline \multirow{4}{*}{$\begin{array}{l}\text { Lead (Pb): } \\
C A S 7439-92-1 ; \\
S F_{\mathrm{o}}=0.047\left(\mathrm{mg} /(\mathrm{kg} \cdot \mathrm{day})^{-1}\right. \\
\text { IACS/EPA }: 2 \mathrm{~A} / \mathrm{B} 2\end{array}$} & \multirow{2}{*}{$I C R_{\mathrm{Pb}}$} & Adults & $1.08 \mathrm{E}-04$ & $8.45 \mathrm{E}-05$ & $2.53 \mathrm{E}-05$ & $2.18 \mathrm{E}-04$ \\
\hline & & Children & $4.34 \mathrm{E}-05$ & $3.38 \mathrm{E}-05$ & $1.01 \mathrm{E}-05$ & $8.73 \mathrm{E}-05$ \\
\hline & \multirow{2}{*}{$P C R_{\mathrm{Pb}}$} & Adults & 137.82 & 107.37 & 32.21 & 277.41 \\
\hline & & Children & 4.70 & 3.66 & 1.10 & 9.46 \\
\hline
\end{tabular}

N o t e : $C A S$ - international identification code of substance; $S F_{\mathrm{o}}$ - factor of carcinogenic potential for peroral penetration; IACS - International Agency on Cancer Studies; US EPA - Agency on Environment Protection in the USA; $I C R_{C d}$ and $I C R_{P b}$ - individual risk to population health conditioned by contamination of food products with cadmium and arsenic; $P C R_{C d}, P C R_{P b}$ - population health risk conditioned by contamination of food products with cadmium and arsenic.

\footnotetext{
${ }^{1}$ Population of BR in 2011 was represented by two subpopulations: 1$)$ children ( $0-6$ years old) - 108,308 people; 2$)$ adults (18 years and older) $-1,271,240$ people.

2 Total ICR of children and adult population conditioned by consumption of FP from all sources of origin (BR, SRF and FAC) contaminated by cadmium and lead.

${ }^{3}$ Hereinafter the assessment of risk level for the population is given under the classification of the US Agency on toxic compounds and morbidity registration (ATSDR) adopted by WHO $(1996,1999,2000)[16,18]$.

${ }^{4}$ Total indicator ICR of children and adult population of all types of localization conditioned by consumption of FP produced in $\mathrm{BR}$ and contaminated with arsenic.
} 
Indicators of carcinogenic risk to population health conditioned by contamination of FP with arsenic in 2011

\begin{tabular}{|c|c|c|c|c|c|}
\hline \multirow[b]{2}{*}{ Cancer type on location } & \multirow{2}{*}{$\underset{\left(\mathrm{mg} /(\mathrm{kg} \cdot \text { day })^{-1}\right.}{\mathrm{SF}_{\mathrm{o}}}$} & \multicolumn{2}{|c|}{ Adults } & \multicolumn{2}{|c|}{ Children } \\
\hline & & $\begin{array}{c}I C R_{A s} \\
\text { (probability) }\end{array}$ & $\begin{array}{c}P C R_{A s} \text { (number } \\
\text { of cases) }\end{array}$ & $\begin{array}{c}I C R_{A s} \\
\text { (probability) }\end{array}$ & $\begin{array}{c}P C R_{A s} \text { (number } \\
\text { of cases) }\end{array}$ \\
\hline Lever & 1.00 & $3.82 \mathrm{E}-04$ & 461.31 & $1.54 \mathrm{E}-04$ & 16.98 \\
\hline Lungs & 2.50 & $9.55 \mathrm{E}-04$ & 1153.27 & $3.84 \mathrm{E}-04$ & 42.46 \\
\hline Bladder & 2.50 & $9.55 \mathrm{E}-04$ & 1153.27 & $3.84 \mathrm{E}-04$ & 42.46 \\
\hline Kidneys & 0.86 & $3.29 \mathrm{E}-04$ & 396.73 & $1.32 \mathrm{E}-04$ & 14.61 \\
\hline Skin & 1.50 & $5.73 \mathrm{E}-04$ & 691.96 & $2.31 \mathrm{E}-04$ & 25.48 \\
\hline All cancer types & & $3.19 \mathrm{E}-03$ & 3856.55 & $1.28 \mathrm{E}-03$ & 141.99 \\
\hline
\end{tabular}

The greatest contribution to the total $I C R^{1}$ conditioned by consumption of contaminated FP is made by arsenic $-86.75 \%$, cadmium makes it to 7.28 and $5.97 \%$ accordingly.

The highest indicators of $P C R$ established for an adult population consuming FP produced in BR are: 3.96,73-1,153.27 additional cases on separate cancer types, in total 3,856.55 cases (table 8). Equivalent indicators for children population were: $P C R_{C d}-314.96$; $P C R_{P b}-277.41$ (table. 7); $P C R_{A s}-141.99$ cases (table 8) additionally to background level of oncologic morbidity.

The size of the attributive individual and population carcinogenic risk for BR population health conditioned by consumption of FP produced in SRF and FAC on lead contamination was $50.32 \%$, on cadmium contamination $-68.59 \%$.

Conclusions. The conducted studies showed that the greatest contribution to the population exposition is made by bread products $(\mathrm{Pb}-32.67 \%, \mathrm{Cd}-32.67 \%$, As $-22.93 \%)$, fish products $(\mathrm{Hg}-73.42 \%, \mathrm{Cd}-39.65 \%, \mathrm{~Pb}-19.45 \%)$, potatoes $(\mathrm{Cd}-45.24 \%, \mathrm{~Pb}-33.43 \%$, nitrates $-16.78 \%)$.

The greatest number of detected maximum levels of probability of non-carcinogenic effects development is connected with consumption of bread products by children population $\left(H Q_{P b}, H Q_{C d}, H Q_{A s}=1.48-1.83\right)$, fish products $\left(H Q_{C d}, H Q_{A s}=1.03-1.16\right)$, vegetables $\left(H Q_{A s}\right.$, $\left.H Q_{\text {нитр }}=1.71-8.80\right)$ and potatoes $\left(H Q_{\text {нитр }}=1.69-2.02\right)$ of local production and imported from SRF and FAC.

While assessing the risks of non-carcinogenic effects emergence in conditions of simultaneous consumption and impact of the studied contaminants, the greatest contribution into non-carcinogenic risks are made by nitrates (32.74\%) and lead (30.98\%), among groups of products - vegetables $(40.55 \%)$.

\footnotetext{
${ }^{1}$ The general indicator of $I C R$ of children and adult population conditioned by consumption of FP of all sources of origin (BR, SRF and FAC) contaminated by cadmium, lead and arsenic.
} 
As for the size of the contribution into total non-carcinogenic risk of FP chemical contaminants, the manifestation of their damaging effects is more probable on the side of bloodcirculating, cardiovascular and endocrine systems.

Chemical contamination of FP delivered from SRF and FAC makes the greatest contribution to forming non-carcinogenic risk among exposed BR population. Attributive (additional) non-carcinogenic risk conditioned by consumption of FP produced in SRF and FAC made:

- on studied contaminants on the level of 46.12-61.03\%;

- on oil and fat and fruit and berries production, fish products and potatoes on the level of $53.12-70.94 \%$;

- on impacting and damaging kidneys, blood circulating, reproductive and endocrine systems at the level of $44.86-50.57 \%$.

The level of carcinogenic risk among adult and children population (8.73E-05-1.14E-04) conditioned by consumption of FP produced in BR, SRF and FAC, chemically contaminated by cadmium and lead is within the permissible levels and is liable to constant control.

Carcinogenic risk of adult and children population (1.28E-03-3.19E-03) conditioned by consumption of FP contaminated by arsenic and produced in BR is above the permissible limits and is not acceptable for the population on the whole. It demands the development and implementation of planned events on health improvement and recovery.

The attributive (additional) carcinogenic risk conditioned by consumption of FP produced in SRF and FAC on lead contamination made 50.32\%, on cadmium $-68.59 \%$.

The conducted study allowed to show the variability range of risk characteristics in conditions of uncertainty connected with the lack (or absence) of realistic data on delivery, study and factual consumption by the population of FP produced in SRF, CIS and FAC.

To reduce the level of uncertainty it is recommended to organize and conduct: dynamic control of expositions and risks for population health conditioned by consumption of FP from critical territories of origin; correcting the plans of laboratory studies of FP in the SHM system; development on suggestions on reduction of population exposition by top FP contaminants produced outside the studied territory; justification and establishment of regional levels of minimal risk and target concentrations of FP chemical contaminants; identification of the population groups who are most susceptible and endangered to hazardous impact of FP chemical contamination; justification of priorities in choosing approaches to taking managerial decisions on reduction of risk for population consuming chemically contaminated FP. 


\section{References}

1. Vasilovskiy A.M., Kurkatov S.V., Skudarnov S.E. Kompleksnye riski dlja zdoro-v'ja naselenija promyshlennyh gorodov Krasnojarskogo kraja, obuslovlennye himicheskim zagrjazneniem ob\#ektov okruzhajushhej sredy [Comprehensive public health risks of industrial cities of the Krasnoyarsk Krai caused by chemical pollution of the environmental objects]. Materialy XI Vserossijskogo s\#ezda gigieni-stov i sanitarnyh vrachej: sbornik statej. Vol I. Ed. by RAMS acad. prof. G.G. Onishchenko, RAMS acad. prof. A.I. Potapov. Jaroslavl': Izd-vo «Kancler», 2012, pp. 356-358.

2. Vasilovskiy A.M. Gigienicheskie osnovy bezopasnosti prodovol'stvennoj pro-dukcii, proizvodimoj v Central'noj Sibiri (na primere Krasnojarskogo kraja): avtoreferat dis. ... doktora medicinskih nauk [Hygienic bases of safety of food products produced in Central Siberia (on the example of the Krasnoyarsk Krai), abstract of the thesis ... of Doctor of Medicine]. Irkutsk, 2013.

3. Dzhatdoeva A.A. Ocenka riska dlja zdorov'ja naselenija, svjazannogo s zagrjazneniem pishhevyh produktov toksichnymi jelementami: dissertacija ... kandidata medicinskih nauk [Assessment of risk to public health associated with the contamination of food with toxic elements: thesis... of the Candidate of Medicine]. Moscow, 2006. 188 p.

4. Zajceva N.V., Maj I.V. Pravovye aspekty ocenki riska dlja zdorov'ja naselenija pri obespechenii bezopasnosti tovarov: mirovoj zarubezhnyj opyt i praktika Tamozhen-nogo sojuza [Legal aspects of public health risk assessment while ensuring the safety of goods: global foreign experience and practice of the Customs Union]. Analiz riska zdorov'ju, 2013, no. 3, pp. 4-16.

5. Zajceva N.V., Shur P.Z. Aktual'nye voprosy metodicheskoj podderzhki ocenki ris-ka dlja zdorov'ja naselenija pri obespechenii bezopasnosti produkcii: mirovoj zarubezhnyj opyt i praktika tamozhennogo sojuza [Current issues of methodological support of public health risk assessment while ensuring the safety of goods: global foreign experience and practice of the Customs Union]. Analiz riska zdorov'ju, 2013, no. 4, pp. 4-16.

6. Katunina A.S., Ushakov A.A. Ocenka vozdejstvija na zdorov'ja na zdorov'e nasele-nija produktov pitanija, zagrjaznennyh himicheskimi veshhestvami [Assessing the impact on public health of chemically polluted food]. Materialy XI Vseros-sijskogo s\#ezda gigienistov $i$ sanitarnyh vrachej: sbornik statej, vol. III. ed. by RAMS acad. prof. G.G. Onishchenko, RAMS acad. prof. A.I. Potapov. Jaroslavl': Izd-vo «Kancler», 2012, pp. 99-101.

7. Kislitsina L.V., Zhigaev D.S., Anan'ev V.Yu., Kiku P.F. Gigienicheskaja ocenka soderzhanija kontaminantov $\mathrm{v}$ produktah pitanija po dannym social'no-gigienicheskogo monitoringa [Hygienic evaluation of the content of contaminants in food products according to public health monitoring]. Materialy Vserossijskogo nauchno-prakticheskoj konferencii s mezhdunarodnym uchastiem Aktual'nye napravlenija razvitija social'no-gigienicheskogo monitoringa $i$ analiza riska zdorov'ju. Ed. by RAMS acad. prof.G.G. Onishchenko, RAMS acad. N.V. Zaitseva. Perm': knizhnyj format, 2013, pp. 187-193.

8. Kleshchina Yu.V., Pavlov N.I. Ocenka riska dlja zdorov'ja naselenija v sisteme kon-trolja za bezopasnost'ju pishhevogo syr'ja. [Public health risk assessment in the system of control over the safety of food raw materials]. Materialy XI Vserossijskogo s\#ezda gigieni-stov $i$ sanitarnyh vrachej: sbornik statej, vol. III. Ed. by RAMS acad. prof. G.G. Onishchenko, RAMS acad. prof. A.I. Potapov. Jaroslavl': Izd-vo «Kancler», 2012, pp. 106-108.

9. Kolnet I.V., Klepikov O.V., Morkovina D.A. Osobennosti zabolevaemosti nasele-nija v svjazi s kontaminaciej pishhevyh produktov [Peculiarities of morbidity due to food contamination]. Materialy XI Vserossijskogo s\#ezda gigienistov i sanitarnyh vrachej: sbornik statej, vol. III. ed. by RAMS acad. prof. G.G. Onishchenko, RAMS acad. prof. A.I. Potapov. Jaroslavl': Izd-vo «Kancler», 2012, pp. 111-113.

10. Kuznetsova I.A., Figurina T.I., Petrova L.Sh., Ivannikova L.I. Mnogosredovoj risk dlja zdorov'ja naselenija ot vozdejstvija himicheskih veshhestv okruzhajushhej sredy na primere goroda Cherepovec [Multimedia public health risk from exposure to chemicals of the environment on the example of the city of Cherepovets]. Materialy XI Vserossijskogo s\#ezda 
gigienistov $i$ sanitar-nyh vrachej: sbornik statej, vol. I. Ed. by RAMS acad. prof. G.G. Onishchenko, RAMS acad. prof. A.I.Potapov. Jaroslavl': Izd-vo «Kancler», 2012, pp. 535-537.

11. Kuz'mina M.V., Efimova N.V., Zaykova Z.A. Pitanie kak faktor, vlijajushhij na zdorov'e naselenija Irkutskoj oblasti [Nutrition as a factor affecting the health of the Irkutsk region]. Analiz riska zdorov'ju, 2013, Perm', no. 3, pp. 48-54.

12. Lim T.E., Voetskiy I.A., Shutova I.A., Yaroshevskiy S.T. Mnogosredovoj risk dlja zdorov'ja detskogo i vzroslogo naselenija ot vozdejstvija himicheskih veshhestv [Multimedia health risk to children and adults from exposure to chemicals]. Materialy XI Vserossijskogo s\#ezda gigienistov $i$ sanitarnyh vrachej: sbornik statej, vol. I. ed. by RAMS acad. prof. G.G. Onishchenko, RAMS acad. prof. A.I. Potapov. Jaroslavl': Izd-vo «Kancler», 2012, pp. 555-558.

13. Litvinova O.S. Razrabotka podhodov $\mathrm{k}$ opredeleniju prioritetnyh kontami-nantov himicheskoj prirody v pishhevyh produktah v rezhime real'nogo vremeni s cel'ju optimizacii sanitarno-jepidemiologicheskogo nadzora: avtoreferat dis. ... kandidata me-dicinskih nauk [Developing of approaches to the identification of priority contaminants of the chemical nature in food products on a real-time basis to optimize the sanitary and epidemiological surveillance: abstract of the thesis ...of the Candidate of Medicine]. Moskva, 2013.

14. Mikhayluts A.P., Vasilovskiy A.M., Skudarnov S.E., Chukhrov Yu.S. Jekologogigienicheskie posledstvija proshlogo jekologicheskogo ushherba $\mathrm{v}$ promyshlennyh regionah Sibiri [Ecological and hygienic consequences of past environmental damage in the industrial regions of Siberia]. Jeko-bjulleten' InJeka, 2008, no. 3 (128). Available at: ineca.ru ?dr=bulletin/arhiv/0128\&pg=016.

15. Onishchenko G.G., Novikov S.M., Rakhmanin Yu.A., Avaliani S.L., Bushtueva K.A. Osnovy ocenki riska dlja zdorov'ja naselenija pri vozdejstvii himicheskih veshhestv, zagrjaznjajushhih okruzhajushhuju sredu [Framework for assessing the public health risk when exposed to chemicals polluting the environment]. Ed. by Rahmanin Ju.A., Onishhenko G.G. Moscow: NII JeCh i GOS, 2002. 408 p.

16. Opredelenie jekspozicii i ocenka riska vozdejstvija himicheskih kontaminantov pishhevyh produktov na naselenie. Metodicheskie ukazanija [Determining exposure and risk assessment of exposure to chemical contaminants in food for the population. Methodical instructions]. Moscow: Federal'nyj Centr gigieny i jepidemiologii Rospotrebnadzora, 2009, 26 p.

17. Rezanova N.V., Nikitin S.V., Fedorov A.S., Ovchinnikova E.L. Ocenka riska dlja zdorov'ja naselenija goroda Omska, svjazannogo s himicheskim zagrjazneniem okruzhajushhej sre-dy. [Public health risk assessment in the city of Omsk, in connection with chemical pollution]. Materialy XI Vserossijskogo s\#ezda gigienistov i sanitarnyh vrachej: sbornik sta-tej, vol. I. ed. by RAMS acad. prof. G.G. Onishchenko, RAMS acad. prof. A.I. Potapov. Jaroslavl': Izd-vo «Kancler», 2012, pp. 659-661.

18. Rukovodstvo po ocenke riska dlja zdorov'ja naselenija pri vozdejstvii himiche-skih veshhestv, zagrjaznjajushhih okruzhajushhuju sredu [Guidelines in public health risk assessment when exposed to chemicals polluting the environment]. Moscow: Federal'nyj centr Gossanjepidnadzora Minzdrava Rossii, 2004. 143 p.

19. Tritscher A., Mijagishima K., Nishida Ts., Brantsa F. Obespechenie bezopasnosti pishhevyh produktov i pitanija dlja zashhity zdorov'ja potrebitelej: 50-letie Komissii Ko-deks Alimentarius [Ensuring food and nutrition safety to protect the health of consumers: the 50th anniversary of the CODEX Alimentarius Commission]. Bjulleten' Vsemirnoj organizacii zdravoohranenija 2013;91:468-468A. Available at: medic-info.org>news/alim/2012-06-09-17.

20. Fedorov A.S. Ocenka riska dlja zdorov'ja naselenija, svjazannogo s himicheskim zagrjazneniem produktov pitanija, vvozimyh na territoriju Omskoj oblasti v 2010 godu [Public health risk assessment associated with chemical contamination of the food imported to the territory of the Omsk region in the year 2010]. Available at: www.omsksanepid.ru/index.php?subaction=showfull\&id...-fqn. 
21. Fetter V.V. Ocenka riska dlja zdorov'ja naselenija himicheskoj kontaminacii produktov pitanija i prodovol'stvennogo syr'ja [Evaluation of chemical contamination of food]. Analiz riska zdorov'ju, 2013. Perm', no. 4, pp. 54-63.

22. Fetter V.V., Berdinskikh N.N., Zav'yalova N.A. Ocenka sostojanija himicheskoj kontaminacii pishhevyh produktov [Public health risk assessment due to the chemical contamination of food products and food raw materials]. Sanitarnyj vrach, 2011, no. 9, pp. 20-23. 